\title{
Increased Excretion of 5-Hydroxyindoleacetic Acid in Urine of Children with Untreated Coeliac Disease
}

\author{
D. N. CHALLACOMBE, G. A. BROWN, S. C. BLACK, and M. H. STORRIE \\ From the Institute of Child Health, University of Birmingham, Birmingham
}

\begin{abstract}
Challacombe, D. N., Brown, G. A., Black, S. C., and Storrie, M. H. (1972). Archives of Disease in Childhood, 47, 442. Increased excretion of 5-hydroxyindoleacetic acid in urine of children with untreated coeliac disease. 24-hour urine excretions of 5-hydroxyindoleacetic acid (5HIAA) have been measured in 13 children with coeliac disease before treatment. All were excreting more 5HIAA than an age-matched group of 22 control children. On introduction of a gluten-free diet clinical remission was accompanied by decreasing 5HIAA excretion. Excretion was normal in cases of acute and chronic diarrhoea and cystic fibrosis.

The test is proposed as an aid to diagnosis and a method of monitoring satisfactory dietary control.
\end{abstract}

Raised blood levels of serotonin have been reported in adults with coeliac disease (Pimparkar, Senesky, and Kalser, 1961; Warner and Cohen, 1962). Serotonin (5-hydroxytryptamine, 5HT), a metabolite of tryptophan, is produced principally by argentaffin cells in the gastrointestinal tract. It is metabolized by tissue monoamine oxidase to 5-hydroxyindolylaldehyde which is further oxidized and excreted in the urine as 5-hydroxyindoleacetic acid (5HIAA). The excretion of 5HIAA in the urine of adults with untreated coeliac disease has also been shown to be raised by some authors (Haverback and Davidson, 1958; Kowlessar et al., 1958; Haverback, Dyce, and Thomas, 1960; Pimparkar et al., 1961; Scriver, 1961; Sleisenger, 1961; Kowlessar, Haeffner, and Benson, 1964; Benson, Kowlessar, and Sleisenger, 1964), though not by others (Connell, Rowlands, and Wilcox, 1960). In those cases where the introduction of a gluten-free diet resulted in clinical and biochemical remission, the levels of blood serotonin (Pimparkar et al., 1961) and urinary 5HIAA (Sleisenger, 1961; Kowlessar et al., 1964; Benson et al., 1964) returned to normal.

Comparable studies in children with coeliac disease have not been reported previously.

\section{Materials and Methods}

24-hour urinary excretion of 5HIAA was estimated in 13 children with untreated coeliac disease aged between

Received 4 November 1971.
6 months and 2 years. The observations were repeated at varying intervals in 8 of these children after the introduction of a gluten-free diet. The diagnosis was confirmed in each case by the demonstration of a flat duodenal mucosa obtained by peroral biopsy, and by the occurrence of clinical remission after the gluten-free diet. We also investigated a group of 8 patients with other gastrointestinal disorders (Table) for evidence of abnormal 5HIAA excretion. Control data were obtained from 22 children of approximately equal age, in hospital for investigation of disorders unconnected with the gastrointestinal tract.

All serotonin-containing foods (Erspamer, 1966) and all drugs were excluded from the diet for 24 hours before, and during, the urine collection.

The urine was collected directly into $10 \mathrm{ml}$ glacial acetic acid and stored at $-20^{\circ} \mathrm{C}$ until analysed.

5HIAA was measured by a method based on that of Macfarlane et al. (1956), with improvements suggested by Mustala, Tuomisto, and Airaksinen (1964). Each urine was analysed in duplicate with added 5HIAA in the second analysis. Recovery of the added 5HIAA was calculated and each analysis figure was corrected using the percentage recovery found. In a series of thirty 24-hour urine specimens, mean percentage recovery of added 5 HIAA was $89 \%$, with a range ( \pm 2 SD) of $78 \cdot 2-99 \cdot 7 \%$.

Collection of reliable 24-hour urine specimens was difficult in the age range of children investigated, and the data were therefore expressed in relation to creatinine excretion. Creatinine was measured by a standard Technicon Auto-Analyser alkaline picrate procedure (Methodology sheet $\mathrm{N}-11 \mathrm{~b}$ ) with a urine dilution step incorporated in the manifold. 
TABLE

Urinary 5HIAA:Creatinine in Control Patients, Coeliac Disease, and Various Gastroenterology Disorders

\begin{tabular}{|c|c|c|c|}
\hline Diagnosis & Sex & Age & $\begin{array}{c}\mu \mathrm{g} \\
\text { 5HIAA/mg } \\
\text { Creatinine }\end{array}$ \\
\hline $\begin{array}{l}\text { Controls ( } 22 \text { cases) } \\
\text { Anaemia } \\
\text { Congenital heart disease } \\
\text { Congenital heart disease } \\
\text { Tracheo-oesophageal fistula } \\
\text { Congenital heart disease } \\
\text { Congenital heart disease } \\
\text { Post meningitis } \\
\text { Inguinal hernia } \\
\text { Chest infection } \\
\text { Otitis media } \\
\text { Chest infection } \\
\text { Upper respiratory tract } \\
\text { infection } \\
\text { Upper respiratory tract } \\
\text { infection } \\
\text { Normal } \\
\text { Tracheal stricture } \\
\text { Normal } \\
\text { Normal } \\
\text { Asthma } \\
\text { Normal } \\
\text { Post febrile convulsions } \\
\text { Asthma } \\
\text { Chest infection }\end{array}$ & $\begin{array}{l}\mathbf{F} \\
\mathbf{M} \\
\mathrm{M} \\
\mathrm{M} \\
\mathrm{M} \\
\mathrm{M} \\
\mathrm{M} \\
\mathrm{M} \\
\mathrm{F} \\
\mathrm{M} \\
\mathrm{M} \\
\mathrm{M} \\
\mathrm{M} \\
\mathrm{M} \\
\mathrm{M} \\
\mathrm{M} \\
\mathrm{M} \\
\mathrm{M} \\
\mathbf{M} \\
\mathrm{M} \\
\mathbf{M}\end{array}$ & $\begin{array}{l}2 \mathrm{wk} \\
2 \mathrm{wk} \\
2 \mathrm{wk} \\
3 \mathrm{wk} \\
1 \mathrm{mth} \\
6 \mathrm{wk} \\
2 \mathrm{mth} \\
2 \mathrm{mth} \\
4 \mathrm{mth} \\
6 \mathrm{mth} \\
6 \mathrm{mth} \\
7 \mathrm{mth} \\
9 \mathrm{mth} \\
9 \mathrm{mth} \\
9 \mathrm{mth} \\
1 \mathrm{yr} \\
1 \mathrm{yr} 2 \mathrm{mth} \\
1 \mathrm{yr} 3 \mathrm{mth} \\
1 \mathrm{yr} 6 \mathrm{mth} \\
1 \mathrm{yr} 8 \mathrm{mth} \\
2 \mathrm{yr} 1 \mathrm{mth} \\
2 \mathrm{yr} 2 \mathrm{mth}\end{array}$ & $\begin{array}{r}14 \cdot 6 \\
15 \cdot 7 \\
20 \cdot 9 \\
13 \cdot 1 \\
6 \cdot 5 \\
23 \cdot 0 \\
16 \cdot 9 \\
13 \cdot 1 \\
20 \cdot 6 \\
15 \cdot 5 \\
18 \cdot 0 \\
19 \cdot 4 \\
15 \cdot 3 \\
14 \cdot 5 \\
16 \cdot 7 \\
10 \cdot 2 \\
10 \cdot 4 \\
10 \cdot 6 \\
11 \cdot 0 \\
9 \cdot 6 \\
12 \cdot 0 \\
8 \cdot 3\end{array}$ \\
\hline Coeliac disease (13 cases) & $\begin{array}{l}F \\
F \\
F \\
F \\
F \\
M \\
F \\
F \\
F \\
M \\
F \\
F \\
M\end{array}$ & $\begin{array}{l}4 \mathrm{mth} \\
6 \mathrm{mth} \\
9 \mathrm{mth} \\
10 \mathrm{mth} \\
11 \mathrm{mth} \\
1 \mathrm{yr} \\
1 \mathrm{yr} 2 \mathrm{mth} \\
1 \mathrm{yr} 2 \mathrm{mth} \\
1 \mathrm{yr} 4 \mathrm{mth} \\
1 \mathrm{yr} 4 \mathrm{mth} \\
1 \mathrm{yr} 5 \mathrm{mth} \\
1 \mathrm{yr} 9 \mathrm{mth} \\
2 \text { yr } 4 \mathrm{mth}\end{array}$ & $\begin{array}{l}25 \cdot 2 \\
43 \cdot 0 \\
22 \cdot 5 \\
38 \cdot 0 \\
14 \cdot 2 \\
19 \cdot 3 \\
33 \cdot 0 \\
15 \cdot 1 \\
26 \cdot 0 \\
18 \cdot 0 \\
23 \cdot 0 \\
20 \cdot 7 \\
23 \cdot 6\end{array}$ \\
\hline $\begin{array}{l}\text { Miscellaneous ( } 8 \text { cases) } \\
\text { Fibrocystic disease } \\
\text { Fibrocystic disease } \\
\text { Acute diarrhoea } \\
\text { Acute diarrhoea } \\
\text { Acute diarrhoea } \\
\text { Chronic nonspecific diarrhoea } \\
\text { Chronic nonspecific diarrhoea } \\
\text { Fibrocystic disease and } \\
\text { coeliac disease }\end{array}$ & $\begin{array}{l}\mathbf{M} \\
\mathbf{M} \\
\mathbf{M} \\
\mathbf{M} \\
\mathbf{M} \\
\mathbf{M} \\
\mathbf{F} \\
\mathrm{F}\end{array}$ & $\begin{array}{l}1 \mathrm{yr} \\
1 \mathrm{yr} 5 \mathrm{mth} \\
5 \mathrm{wk} \\
4 \mathrm{mth} \\
2 \mathrm{yr} 1 \mathrm{mth} \\
2 \mathrm{mth} \\
11 \mathrm{mth} \\
1 \mathrm{yr} 7 \mathrm{mth}\end{array}$ & $\begin{array}{r}11 \cdot 7 \\
10 \cdot 8 \\
20 \cdot 0 \\
18 \cdot 6 \\
4 \cdot 6 \\
13 \cdot 3 \\
10 \cdot 9 \\
23 \cdot 8\end{array}$ \\
\hline
\end{tabular}

Nominal 24-hour excretions of 5HIAA were expressed as $\mu \mathrm{g}$ HIAA/mg creatinine.

\section{Results}

The values of the 5HIAA : creatinine ratio in relation to age in the patients with coeliac disease and control children are shown in Fig. 1 and the Table. The value of this ratio is high in early infancy, falling to a lower level at 1 year. The high initial value of the ratio is due to an increased rate of 5HIAA excretion in early infancy and coincides with the rising levels of whole blood 5HT occurring during this period (Hazra, Benson, and Sandler, 1965). The subsequent decrease in ratio is not due to an absolute decrease in 5HIAA excretion, but to a reduced increment rate, accompanied by a constantly increasing creatinine excretion rate. Between 1 year and 2 years 2 months, the upper limit of our age group, the ratio remains constant.

Although ratios in some untreated coeliac children over 1 year of age were lower than values in younger controls, when compared to controls of appropriate age, no overlap of these ratios occurred. Notwithstanding the overlap introduced by the age factor, the mean value for the ratio in the coeliac children was greater $(P=0.001)$ than the mean for the control group. After the introduction of a gluten-free diet (Fig. 2), the ratio decreased in all 8 cases in whom follow-up studies were performed. In half of the cases the ratio fell to levels indistinguishable from control values, but in the other half, values were still above the normal controls. It is possible that after a longer period of treatment all 8 values would have returned to normal. After treatment the ratios fell to $39-89 \%$ of their pretreatment value, with an average fall for the 8 patients to $63 \%$. The fall in ratio on treatment was entirely due to decreased 5HIAA excretion. Urinary creatinine values, before and after the introduction of a gluten-free diet, were unchanged. The 5HIAA : creatinine ratio in the small group of other gastrointestinal disorders did not exceed control values for their age, with the exception of one child with both coeliac disease and fibrocystic disease. In this patient the value was within the high range characteristic of patients with coeliac disease. Two weeks after a gluten-free diet the ratio had fallen to a normal value.

\section{Discussion}

The increased excretion of 5HIAA in the urine of children with untreated coeliac disease agrees with previously reported findings in adults with this disorder. The cause of increased 5IHAA excretion is unknown. The metabolic pathway leading to the production of 5HIAA has been studied in adults by L-tryptophan loading tests, and an augmented shunt of the 5HT to 5HIAA pathway shown in the untreated patients (Kowlessar et al., 1964). Raised levels of whole blood 5HT have also been reported in adults with untreated coeliac disease and these fell to normal after a gluten-free diet (Pimparkar et al., 1961). Though 


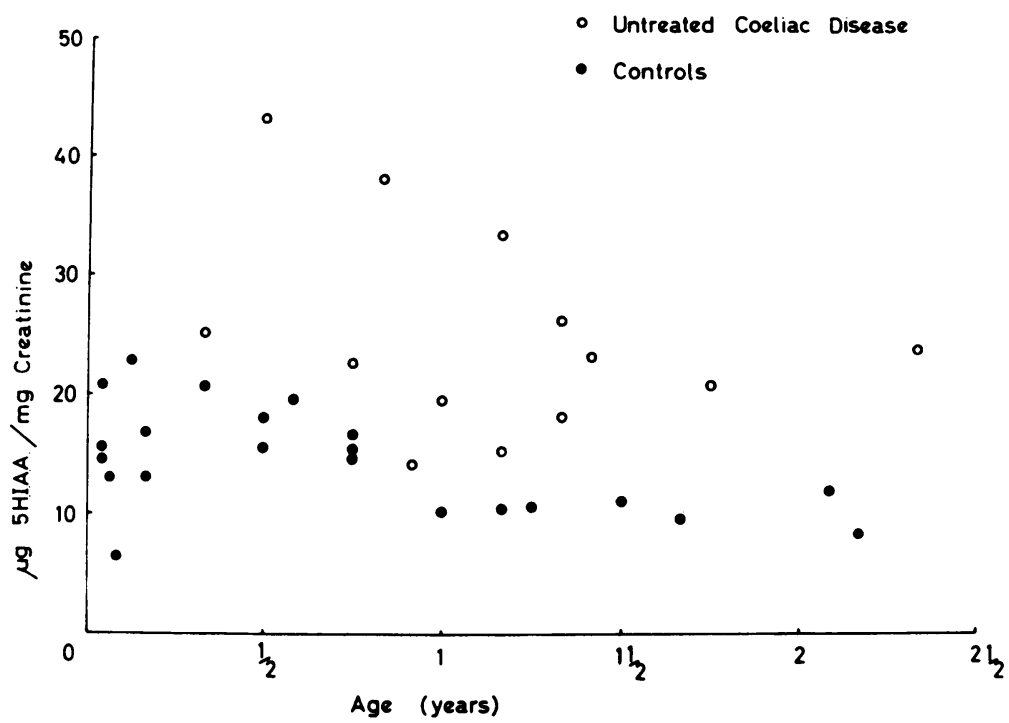

FIG. 1.-5HIAA: creatinine ratios in 24-hour urine collections from children with untreated coeliac disease (o), and agematched controls $(\bullet)$.

comparative studies of whole blood 5HT levels have not been performed in children, our data suggest that it would be similarly abnormal in children with untreated coeliac disease.

Increased urinary excretion of other trytophan metabolites, such as indole-3-acetic acid and indican, have also been reported in coeliac disease (Haverback et al., 1960; Kowlessar et al., 1964). The raised

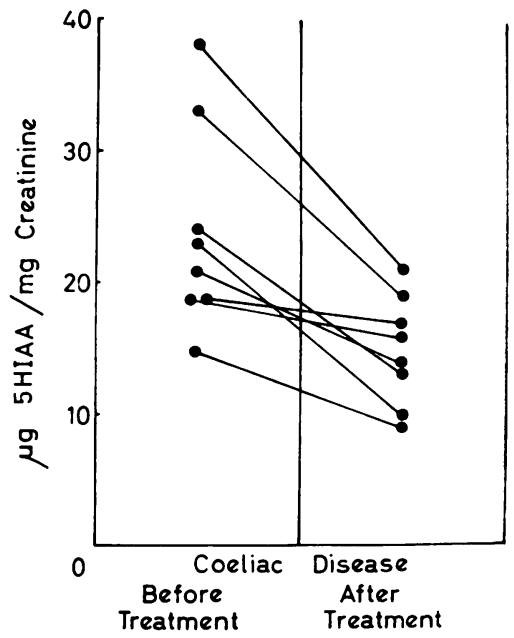

FIG. 2.-5HIAA: creatinine ratios in 8 patients with coeliac disease before and during treatment with a glutenfree diet. levels of these metabolites probably result from an abnormal small intestinal flora, or a normal colonic flora acting on unabsorbed proteins or amino acids (Kowlessar et al., 1964; Fordtran, Scroggie, and Potter, 1964). The administration of tetracycline to adults with untreated coeliac disease lowered the urinary excretion of indole-3-acetic acid and indican, but did not affect the raised levels of 5HIAA (Kowlessar et al., 1964). As urinary 5HIAA excretion was also unaffected by tryptophan or serotonin infusion into the colon, the increased excretion of 5HIAA in coeliac disease is probably unrelated to colonic bacterial flora (Fordtran et al., 1964).

An increased rate of 5HT breakdown resulting from increased tissue monoamine oxidase activity might also explain the increased urinary levels of 5HIAA. The enzyme has been estimated and found to be low in the duodenal mucosa and normal in plasma (Challacombe, Sandler, and Southgate, 1971), and it seems unlikely therefore that increased monoamine oxidase activity is primarily responsible for the increased urinary excretion of 5HIAA. Since the excretion of 5HAA decreases on withdrawal of dietary gluten, gluten itself may have a a direct effect on the argentaffin cells resulting in increased release of 5HT. As published family studies of coeliac disease (Carter, Sheldon, and Walker, 1959) suggest that the incidence of this disease is greater among relatives of affected individuals than in the general population, the 
possibility of an inborn abnormality of argentaffin cell metabolism in this disease must also be considered.

Though our investigations in other gastrointestinal disorders suggest that raised 5HIAA excretion is a specific manifestation of coeliac disease, a non-specific association with villous atrophy has not yet been excluded. Further work on 5HIAA excretion in other gastrointestinal disorders (Ammann, 1965) characterized by villous atrophy will also be necessary.

The measurement of 5HIAA : creatinine ratio in 24-hour urine collections may prove to be a useful aid in the laboratory diagnosis and dietary management of children with coeliac disease. Though the collection of a 24-hour specimen of urine is difficult in this age group, it may be possible to use the 5HIAA : creatinine ratio from urines collected over shorter intervals of time.

We are indebted to Professor Charlotte $M$. Anderson for help and advice, and to the nursing staff of the Birmingham Children's Hospital.

\section{REFERENCES}

Ammann, R. (1965). Celiac and celiac-like mucosal changes of the small intestine. Gastroenterologia (Basel), 103, 295.

Benson, G. D., Kowlessar, O. D., and Sleisenger, M. H. (1964). Adult celiac disease with emphasis upon response to the glutenfree diet. Medicine, 43, 1.

Carter, C. O., Sheldon, W., and Walker, C. (1959). The inheritance of coeliac disease. Annals of Human Genetics, 23, 266.

Challacombe, D. N., Sandler, M., and Southgate, J. (1971) Decreased duodenal monoamine oxidase activity in coeliac disease. Archives of Disease in Childhood, 46, 213.

Connell, A. M., Rowlands, E. N., and Wilcox, P. B. (1960). Serotonin, bananas, and diarrhoea. Gut, 1, 44.
Erspamer, V. (1966). Occurrence of indolealkylamines in nature. In 5-Hydroxytryptamine and Related Indolealkylamines (Handbuch der experimentellen Pharmakologie, vol. 19), p. 132. Ed. by V. Erspamer. Springer, Berlin.

Fordtran, J. S., Scroggie, W. B., and Potter, D. E. (1964). Colonic absorption of tryptophan metabolites in man. Fournal of Laboratory and Clinical Medicine, 64, 125

Haverback, B. J., and Davidson, J. D. (1958). Serotonin and the gastrointestinal tract. Gastroenterology, 35, 570.

Haverback, B. J., Dyce, B., and Thomas, H. V. (1960). Indole metabolism in the malabsorption syndrome. New England Fournal of Medicine, 262, 754.

Hazra, M., Benson, S., and Sandler, M. (1965). Blood 5-hydroxytryptamine levels in the newborn. Archives of Disease in Childhood, 40, 513.

Kowlessar, O. D., Haeffiner, L. J., and Benson, G. D. (1964). Abnormal tryptophan metabolism in patients with adult celiac disease, with evidence for deficiency of Vitamin $\mathbf{B}_{\mathbf{6}}$. Fournal of Clinical Investigation, 43, 894.

Kowlessar, O. D., Williams, R. C., Law, D. H., and Sleisenger, M. H. (1958). Urinary excretion of 5-hydroxyindoleacetic acid in diarrheal states, with special reference to nontropical sprue. New England fournal of Medicine, 259, 340.

Macfarlane, P. S., Dalgliesh, C. E., Dutton, R. W., Lennox, B., Nyhus, L. M., and Smith, A. N. (1956). Endocrine aspects of argentaffinoma, with special reference to the use of urinary 5-hydroxyindoleacetic acid estimations in diagnosis. Scottish Medical fournal, 1, 148.

Mustala, O. O., Tuomisto, J. J., and Airaksinen, M. M. (1964). A new modification for the determination of 5-hydroxyindoleacetic acid (5HIAA) in urine. Scandinavian fournal of Clinical and Laboratory Investigation, 16, 655.

Pimparkar, B. D., Senesky, D., and Kalser, M. H. (1961). Blood serotonin in nontropical sprue. Gastroenterology, 40, 504.

Scriver, C. R. (1961). Abnormalities of tryptophan metabolism in a patient with malabsorption syndrome. Fournal of Laboratory and Clinical Medicine, 58, 908.

Sleisenger, M. H. (1961). Clinical and metabolic studies in nontropical sprue. New England fournal of Medicine, 265, 49.

Warner, R. R. P., and Cohen, N. (1962). Blood serotonin in malabsorption states. American fournal of Digestive Diseases, 7, 553.

Correspondence to Dr. D. N. Challacombe, The Institute of Child Health, Francis Road, Birmingham B16 8ET. 